Acta Technologica Agriculturae 2

Nitra, Slovaca Universitas Agriculturae Nitriae, 2015, pp. 29-35

\title{
COMPARATIVE ANALYSIS OF PINE NEEDLES AND COAL FOR ELECTRICITY GENERATION USING CARBON TAXATION AND EMISSION REDUCTIONS
}

\author{
Alok DHAUNDIYAL*, Pramod CHANDRA TEWARI
}

Govind Ballabh Pant University of Agriculture and Technology, College of Technology, Pantnagar, U. K, India

\begin{abstract}
Mitigating global climate change via emission control and taxation is promising for strengthening the economic benefits of bioenergy generation and utilization. This study examines the cost effectiveness of pine needles as an alternative fuel for off-grid electricity generation in India. We first examined the changes of prices in coal for electricity generation due to $\mathrm{CO}_{2}$ emission reductions and taxes using experimental data of gasification plants. The time value of money and depreciation scale were used to find out the real levellized cost of electricity generation of gasification plants. Then, the costs of electricity generation fuelled by pine needles and coal were estimated using the cost analysis method. Our results indicate that pine needles would have more competitive edge than coal if emission had taxed at about an emission tax INR $525.15 \mathrm{Mg}^{-1}$ of $\mathrm{CO}_{2}$ (US\$ 8.4), or higher would be needed for pine needles at a yield of $202.176 \mathrm{dry} \mathrm{Mg} \mathrm{hm}{ }^{-2} \mathrm{yr}$. The price of coal used for electricity generation would have significantly increased if global $\mathrm{CO}_{2}$ emission had abridged by $20 \%$ or more. However, pine needles were found a much better fuel source with an increasing yield of $5.05 \mathrm{Mg} \mathrm{hm}^{-2}$ $\mathrm{yr}$ (with respect to power generation) and $2.335 \mathrm{Mg} \mathrm{hm}^{-2} \mathrm{yr}$ (with respect to feedstock production).
\end{abstract}

Keywords: loose biomass, fossil fuel, electricity production, $\mathrm{CO}_{2}$ emission and taxes, cost analysis

Pine trees are abundant in altitudes ranging from $1000 \mathrm{~m}$ to $2000 \mathrm{~m}$ in the Himalayan region of India. Needles that fall from pine trees have traditionally been used by local communities for carpeting cattle sheds, for cooking purposes during monsoon, and as fertilizer. However, pine needles also pose a significant risk, given their highly combustible nature, which results in frequent forest fires that cause losses to biodiversity, human life, and wildlife. In order to address the problem of recurrent damage due to forest fires, there have been several attempts to identify alternate uses for pine needles. One of them is to utilize pine needles as an alternative means for grid power generation in northern hill regions. Biomass-based power is also relevant in the context of climate change and global warming as biomass-based power generation is net carbon neutral (Hall et al., 1993).

Continued deglaciation has profound impacts on the hydrological regimes of river basins originating in the Himalayas. It has been noticed that river discharges are likely to increase for some time due to accelerated melting of glacier, but as the glaciers' water storage capacity is reduced, the flow is likely to decline. Indications of shifting in the hydrographs and bank line of some rivers in Uttarakhand, especially the Alaknanda have already been observed. The hydrological implications of such deglaciation are expected to be most severe in the arid parts of the Himalayan region. Areas in the high mountains and on the high plateaus not covered in perennial snow and ice are underlain by permafrost. Recent studies show that the extent of permafrost is shrinking and the active layer thickness (the upper portion of the soil that thaws each summer) is increasing, and, further, that this has altered the hydrological cycle, vegetation composition, and carbon dioxide that appear to be linked to permafrost degradation (Lawrence and Slater, 2005). Over the last two decades, forest fires in the greater Himalayan belt of the hill regions of India, which have good access to biomass but no access to grid power, have become the most widespread local threat to forests with their increased frequency, wider range and severity. Power generation capacity is mainly based on thermal and hydro, with about $11 \%$ from renewable energy. In India, of $210 \mathrm{GW}$ electricity generation capacities, $66 \%$ is derived from coal, with planned additions of $76 \mathrm{GW}$ and $93 \mathrm{GW}$ during the $12^{\text {th }}$ and the $13^{\text {th }}$ five-year plans, respectively, and generated 665 million tonnes of carbon dioxide. Thus, resulted in an estimated 80000 to 115000 premature deaths and 20 million asthma cases from exposure to $\mathrm{PM}_{25}$ pollution, which cost the public and the Government an estimated INR 16000 to 23000 crores (US\$ 3.2-4.6 billion) (Guttikunda and Jawahar, 2014). Coal combustion residuals (CCRs) are a collective term referring to the residuals produced during the combustion of coal, regardless of ultimate utilization or disposal. In India, presently, coal-based thermal power plants are releasing 105 MT of CCRs, which present major environmental problems. The combustion of fossil fuels is the major source of greenhouse gases (GHGs) (Carlo et al., 2005). In addition, the forest biomass also plays an important global environmental role. Economic analysis beyond biomass feedstock production, though limited, has also gained momentum recently. Biomass co-firing with coal in electricity generation has been demonstrated to be technically feasible and, in some cases, cost effective as well (Nienow et al., 1999). In July 2010, carbon taxation on emission was set to be INR $50 \mathrm{t} \mathrm{t}^{-1}$ (US\$ $1.07 \mathrm{t}^{-1}$ ). In 2014, emission taxes revised to INR $100 \mathrm{t}^{-1}$ 
(US\$ $1.60 \mathrm{t}^{-1}$ ) of $\mathrm{CO}_{2}$ emission (Dogra, 2010). In India, coal has been used as a primary fuel for more than half of the country's electricity generation (Pearson, 2010). According to the Kyoto Protocol, there is no fixed percentage for nonannex parties (including India and China) to curb emission; moreover, a clean development mechanism (CDM) will be implemented (APP, 2010). Over the time period since 1900 to 2005, India's share to the global total of cumulative energyrelated $\mathrm{CO}_{2}$ emission was $2 \%$. Policies in India related to green gas emission have included the use of nuclear power and renewable energy, a target to increase the energy efficiency by $20 \%$ by $2016-2017$, and building codes designed to reduce energy consumption (Stern, 2007; Jones et al., 2008).

To this end, we conducted a comparative analysis of pine needles and coal in terms of both feedstock and electricity generation under different $\mathrm{CO}_{2}$ emission reduction and taxation from 2004 to 2014. Pine needles from the Himalayan forest were experimentally as well as analytically examined and compared with coal. Instead of externalities and nominal discount factor, we used the real discounting factor for evaluating the real levellized cost of electricity of both the plants (coal as well as loose biomass). We simulated market equilibrium energy prices at $\mathrm{CO}_{2}$ emission tax rates, which are fixed by the Government of India for all the power plant industries. This methodology was adopted to avoid determining carbon price, which varies tremendously with the budgetary plan of country.

\section{Material and methods}

\section{Cost analysis}

A method for assessing the economics of a power plant is to calculate the unit cost of electricity $(C O E)$ produced by the plant (Horlock, 1995). In order to evaluate this cost, the following formulation is used:

A - unit capital cost $\left(\$ \mathrm{kWh}^{-1}\right)$;

$\mathrm{B}$ - plant net thermal efficiency;

C - fuel cost $\left(\$ \mathrm{kWh}^{-1}\right)$;

$\mathrm{D}$ - operating and maintenance (O \& M) cost.

If indicative earnings from by-products are excluded to simplify the calculations, the cost of electricity is given by:

$$
\operatorname{COE}=(A+C+D)
$$

where:

C - $f(B)$, and $D$ is conservatively estimated to be $D=15 \%$ of $(A+C)$. Gasification plant capital cost was based on $85 \%$ utilization, 20 -year life, $15 \%$ capital recovery cost and type of feedstock (land and civil works, which constitute $15 \%$ of the capital investment, were allowed as $\mathrm{O} \& \mathrm{M}$ expenditure every year)

The price of coal comparatively to pine needles was evaluated on the basis of their calorific and heating values:

$$
F C_{1}=F C_{2} \times\left(\frac{C V_{1}}{C V_{2}}\right)
$$

where:

$F C_{1}$ - the price of biomass

$F C_{2}$ - the price of imported coal from other states
$C V_{1}$ - the calorific value of biomass

$\mathrm{CV}_{2}$ - the calorific value of imported coal. Another term is heat rate that effect the comparative cost evaluation of biomass

where: $\quad F C_{1}=F C_{2} \times\left(\frac{C V_{1}}{C V_{2}}\right) \times\left(\frac{H R_{2}}{H R_{1}}\right)$

$H R_{1}$ and $H R_{2}$ - the heat rate of biomass and coal power plants respectively

In 2012, Central Electricity Regulatory Commission (CERC) constituted a committee to visit several biomass power plants and examine various issues. Central Electricity Authority (CEA) has fixed $\mathrm{HR}_{2}$ as $2922.88 \mathrm{kcal} \mathrm{kWh}^{-1}$ (CEA, 2000).

The experimental analysis of pine needles have $H R_{2}$ as $2949.88 \mathrm{kcal} \mathrm{kWh}^{-1}$ and the calorific value CV1 $18.57 \mathrm{~kJ} \mathrm{~kg}^{-1}$ (Dhaundiyal and Gupta, 2014).

\section{Economic evaluation measures matrix}

\section{Net present value}

The net present value (NPV) of a project is a way of investigating costs (cash outflows) and revenues (cash inflows) together (Palm and Qayum, 1985).

The NPV analysis is recommended when evaluating investment features and decisions such as mutually exclusive projects and social costs. With mutually exclusive projects, NPV does not fail to recognize the difference in the size of investment alternatives (i.e. a large investment allows the investor to invest more at a favourable return):

$$
\begin{gathered}
N P V=\frac{\sum F_{n}}{(1+d)^{n}} \\
0 \leq n \leq N \\
P V F_{n}=\frac{1}{(1+d)^{n}} \\
N P V=P V F_{n} \times F_{n}
\end{gathered}
$$

where:

$P V F_{n}-$ present value interest factor

$N P V$ - net present value

$F_{n} \quad-$ net cash flow in year $(n)$

$N$ - analysis period

d - annual discount rate

\section{Total life-cycle cost}

The total life-cycle cost (TLCC) analysis is used to evaluate differences in costs and the timing of costs between alternative projects. TLCCS are the costs incurred through the ownership of an asset over the asset's life cycle or the period of interest to the investor (Brown and Yanuck, 1980).

$$
T L C C=\sum \frac{C_{n}}{(1+d)^{n}}
$$

$0 \leq n \leq N$

where:

TLCC- present value of TLCC

$C_{n}-$ cost in period $n$ (investment costs include financial 
charges as appropriate, expected salvage value, nonfuel $O \& M$ and repair costs, replacement costs, and energy costs)

\section{Levellized cost of energy}

The levellized cost of energy ( $L C O E$ ) is that cost, if assigned to every unit of energy generated (or saved) by the system over the analysis period, will equal the TLCC when discounted back to the base year. $L C O E$ is recommended for use when ranking alternatives have given a limited budget simply as the measure will provide a proper sequence of the alternatives, which may then be selected until the budget is expended. LCOE is not recommended when selecting among mutually exclusive alternatives because of differing investment sizes. $L C O E$ are mainly distinguished by inflation rate during an analysis period. We considered real levellized cost of energy (RLCOE), which excluded nominal discount rate that is correlated to inflation rate. The cost of energy generation remains perhaps the single most important factor in determining whether an energy technology can reach commercialization. LCOE serves as such a metric. All known parameters are factored into calculation, and the end result is a price per kilowatt hour. $\angle C O E$ is a long-term cost concept which accounts for all the resources and physical assets required to yield a stream of electricity output. LCOE represents a ,break-even' value that a power provider would need to charge in order to validate an investment in a particular energy undertaking (Islegen and Reichelstein, 2011):

$$
\begin{aligned}
& R L C O E=\frac{\text { total life cycle cost }}{\text { total life time energy generation }}=
\end{aligned}
$$

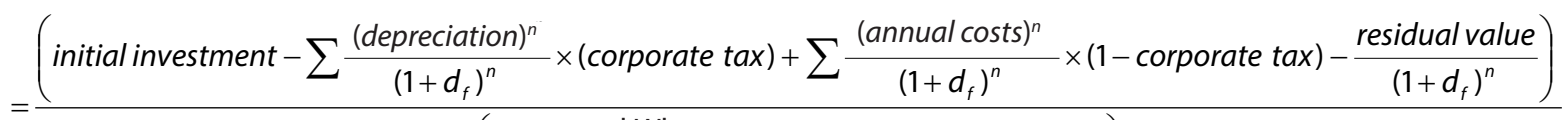

$$
\begin{aligned}
& \left(\frac{\sum \text { initial } \frac{\mathrm{kWh}}{\mathrm{kW}} \times(1-\text { system degradation rate })^{n}}{\left(1+d_{f}\right)^{n}}\right)
\end{aligned}
$$

where:

e - inflation rate

$d_{n}$ - nominal discount rate

$d_{f}$ - discount rate in the absence of inflation (real)

For all economic measures, except payback, salvage value is treated as a revenue stream at the end of the evaluation life; salvage value (residual value) is not accounted for when calculating depreciation for tax purposes using an accelerated depreciation method. However, an asset may not be depreciated below a reasonable salvage value $(\mathrm{CCH}, 1992)$.

\section{Comparisons of biomass and fossil fuel energy production}

The comparative analysis was based on both feedstock and energy generation. Coal and pine needles were considered. Pine needles production costs were derived from the Uttarakhand Renewable Energy Agency data base (UREDA, 2014). It was reported about litter fall rates for longleaf pine based observation of basal area and litter fall (Gresham, 1982). The pine production equation was used to determine the annual yield of pine needles per hectare per year:

$$
Y=-357.78+1020.82(B A)^{\frac{1}{2}}
$$

where:

\begin{tabular}{|c|c|c|}
\hline Parameters & Loose biomass & Conventional pulverized coal \\
\hline Capacity & $120 \mathrm{~kW}_{\mathrm{e}}$ & 120 kW (thermal) \\
\hline Initial capital cost of plant & US\$ 45351.88 & US\$ 32394.20 \\
\hline Fixed $O \& M$ costs & US\$ 6997.15 & US\$ 10495.72 \\
\hline Heat rate in kcal kWh-1 & 2949.88 & 2922.88 \\
\hline Producer gas engine cost & US\$ 4049.27 & $N / A^{*}$ \\
\hline Turbine and boiler costs & N/A & US\$ 8813.18 \\
\hline Fuel cost in $t$ & US\$ 20 & US\$ 25.92 \\
\hline Transportation cost in $t$ & US\$ 15.63 & US\$ 25.66 \\
\hline Residual value per year & US\$ 2906.61 & US\$ 2360.367 \\
\hline Corporate tax ${ }^{* *}$ & $34 \%$ of plant income & $34 \%$ \\
\hline Discount factor (d) (real) & $4.9 \%$ & $10.9 \%$ \\
\hline Variable $(O \& M)$ costs & US\$ 6753.482 & US\$ 4478.582 \\
\hline
\end{tabular}

Table 1 Costs and performance characteristics of electricity generating systems 
The production cost includes procurement cost only since pine needle litter is considered as forest waste. Both fixed and variable costs were incorporated. Building cost was assumed to be INR 700000 (US\$ 11 247.69).

To determine the national average production cost of pine needles, we first identified the median production cost in each pine needles-producing hill states (Jammu and Kashmir, Uttarakhand and Himachal Pradesh) of India. The energy density of pine needles was experimentally found to be $1.77 \mathrm{GJ} \mathrm{m}^{-3}$.

Production costs including delivery costs were calculated based on per unit energy produced, which were then compared to the national average price of delivered coal in the base year and under various $\mathrm{CO}_{2}$ emission reduction and tax scenarios.

Two gasification systems were analysed: loose biomass and conventional pulverized coal. These two systems were assumed to operate at commercial scale for 15 years. The straight line method (SLM) with $10 \%$ salvage value (residual value) was adopted to find out the depreciation cost of gasification plant and engine. The 'written-down value' method or 'diminishing balance method' is also another method for depreciation, but in order to avoid imbalance depreciation (depreciation rate is high at the earlier useful lifecycle to the end of plant life cycle) each year, we used the SLM. The costs include initial capital investment and those for operating and maintenance (fixed cost only). The fuel cost was determined based on the price of delivered pine needles and coal. The loss assumed was negligible during transportation, so it was excluded from the economic analysis of fuel cost. Discounting factor depended on salvage cost and net cash inflow, hence discounting factor would differ for both the plants. The delivery cost for pine needles was estimated at US\$ 19.347 at the rate of US\$ 0.07 per km. Using these data, the costs per unit of electricity generated from each system were estimated. The electricity production cost of biomass gasification was then compared with the cost of conventional pulverized coal. All the costs and prices in this analysis were measured using 2004 constant Indian Rupee. Till 2013, the carbon taxation on emission was fixed to be INR 50 per tonne. In 2014, the taxation revised to be INR 100 per tonne of $\mathrm{CO}_{2}$ emission. By-product indicative earnings were excluded from analysis.

\section{Results and discussion}

\section{Impact of carbon taxation and emission on energy prices}

Reductions in $\mathrm{CO}_{2}$ would cause the cost of coal transported to power plants to increase progressively as the marginal cost of controlling emissions will be increased with percentage reduction of $\mathrm{CO}_{2}$. The coal price would slightly change only if $\mathrm{CO}_{2}$ emission in plant is reduced by less than $10 \%$. However, the change in pine needles price would decrease when $\mathrm{CO}_{2}$ emission in plant is mitigated by less than $10 \%$. For a $40 \%$ emission reduction (break-even point), there will be the same energy generation cost per GJ. The comparative change in the marginal cost of pine needles is much less than its energy density; hence, the cost of pine needles for the same percentage emission reductions is monotonously decreasing with respect to coal. If $30 \%$ plant emissions were reduction, coal price would significantly increase. For $50 \%$ emission reduction, the cost of coal would be almost 1.1 times more than the base year. Levying carbon tax would cause the coal price to increase proportionality to the tax rate. The coal price in the India market would soar up by $2.58 \%$ for each INR $52.25 \mathrm{Mg}^{-1} \mathrm{CO}_{2}$ tax levied (Table 2).

Table 2 Percentage changes in the price of delivered coal under different $\mathrm{CO}_{2}$ percentage emission reduction and taxation

\begin{tabular}{|c|c|}
\hline Variables & $\begin{array}{l}\text { Change in coal price } \\
\text { (\%, base year 2004) }\end{array}$ \\
\hline \multicolumn{2}{|c|}{$\mathrm{CO}_{2}$ emission reductions } \\
\hline $10 \%$ reduction & 1.45 \\
\hline $20 \%$ reduction & 2.74 \\
\hline $30 \%$ reduction & 4 \\
\hline $40 \%$ reduction & 5 \\
\hline $50 \%$ reduction & 5.5 \\
\hline \multicolumn{2}{|c|}{$\mathrm{CO}_{2}$ emission taxes } \\
\hline INR $52.25 \mathrm{Mg}^{-1} \mathrm{CO}_{2}$ & 1.612 \\
\hline INR $104.36 \mathrm{Mg}^{-1} \mathrm{CO}_{2}$ & 3.22 \\
\hline INR $156.74 \mathrm{Mg}^{-1} \mathrm{CO}_{2}$ & 5 \\
\hline INR $390.63 \mathrm{Mg}^{-1} \mathrm{CO}_{2}$ & 12.3 \\
\hline
\end{tabular}

\section{Loose biomass feedstock production}

To examine the economic efficiency of loose biomass, pine needles production systems, we compared the production costs (annualized costs of loose biomass) with the price of delivered coal. Instead of comparing the farm gate price of loose biomass with wellhead price of coal, we added delivery costs into the analysis for two reasons:

1. investors are more interested in delivered prices than crude or wellhead prices,

2. delivery costs for pine needles and coal per GJ are significantly varied.

Hence, involving delivery costs would much better demarcate the pine needles and coal's competitive facet. At a yield of $1.5 \mathrm{Mg} \mathrm{hm}^{-2} \mathrm{yr}$, the loose biomass production and delivery costs were estimated at about US\$ $1.26 \mathrm{GJ}^{-1}$ for pine needles (Figure 1). The average price of coal (2013-2014) is US\$ $1.06 \mathrm{GJ}^{-1}$ (Sengupta, 2014). Pine needles production costs have to be reduced by almost $16 \%$ in order to compete with coal. The yield at which pine needles production costs would be comparable with coal would be $2.85 \mathrm{Mg} \mathrm{hm}^{-2} \mathrm{yr}$ (basal area is 1.77 hectares). At current yield and production costs, pine needles would not be comparable unless carbon emissions were taxed at about $52.25 \mathrm{Mg}^{-1} \mathrm{CO}_{2}$. An increase in the yield of pine needles would improve the cost effectiveness of energy generation over coal. When pine needles yield reaches $2.335 \mathrm{Mg} \mathrm{hm}^{-2} \mathrm{yr}$ and $3.82 \mathrm{Mg} \mathrm{hm}^{-2}$ $\mathrm{yr}$, the required $\mathrm{CO}_{2}$ emission tax would be reduced to INR 325 (US\$ 5.2) and INR 286.18 (US\$ 4.57) per tonne of $\mathrm{CO}_{2}$ respectively. Consequently, $\mathrm{CO}_{2}$ emissions would have to be reduced by $15-35 \%$ for pine needles to become competitive with coal in terms of feedstock production (Figure 2). 


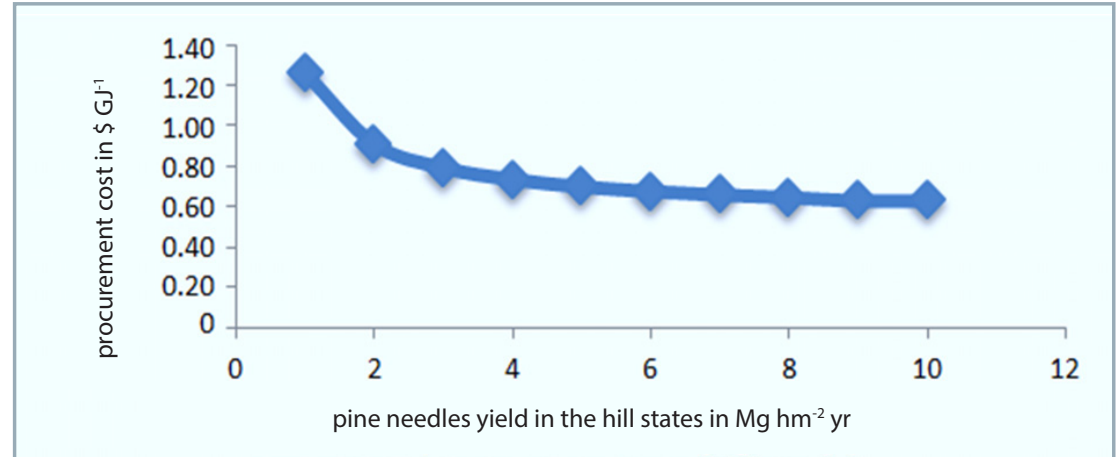

Figure 1 Pine needles production cost at different yield

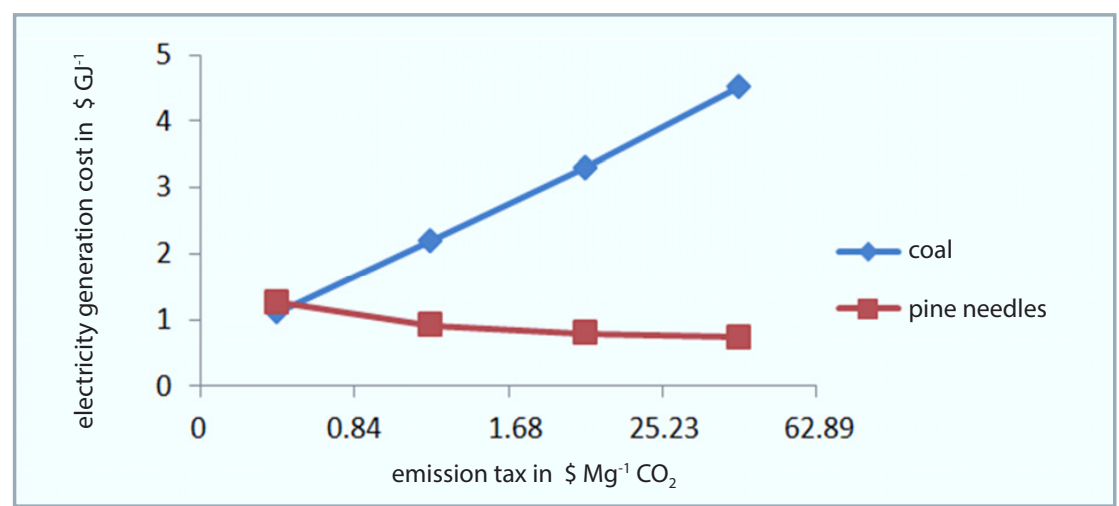

Figure 2 Production cost of pine needles and coal with various carbon taxation

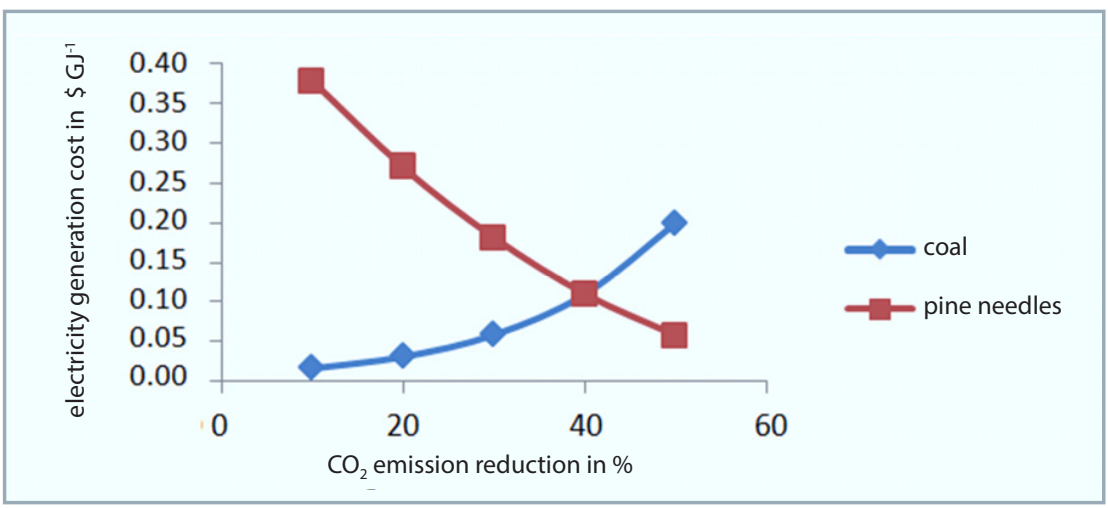

Figure 3 Production costs of pine needles and coal under different $\% \mathrm{CO}_{2}$ emission reduction

\section{Electricity generation}

Without considering $\mathrm{CO}_{2}$ emission costs, electricity generation costs using the conventional pulverized coal and loose biomass gasification systems were estimated to be $0.13 \mathrm{US} \mathrm{kWh}^{-1}$ and 0.128 US\$ $\mathrm{kWh}^{-1}$ respectively, whereas the RLCOEs of electricity of coal and loose biomass plants were 0.21 US\$ $\mathrm{kWh}^{-1}$ and 0.18 US\$ $\mathrm{kWh}^{-1}$ respectively. Compared to the pulverized coal gasification, the loose biomass gasification system would be more costly in the plant size category. The initial investment on a per unit plant capacity basis for the loose coal pulverized system if we were to estimate the cost of electricity with respect to thermal utility. Therefore, without enhancing the quality of electricity generating equipment or involving environmental benefits, it is impossible for pine needles to compete with coal. Excluding environmental and social benefits to local market, if the non-fuel cost of pine needles is reduced by $31 \%$, pine needles would be able to compete with coal at delivered price of US\$20 $\mathrm{Mg}^{-1}$ or lower.

For making loose biomass systems competitive irrespective of application, we would have to reduce the marginal cost or increase the plant capacity of the loose biomass system. Meanwhile, the fuel cost (transportation cost excluded) of pine needles (loose biomass) had a share of $44 \%$ of the electricity generation cost per kWh (non-fuel cost is excluded), whereas it was about $40 \%$ for coal. Thus, reducing the fuel cost through increasing the yield and efficiency of the pine needles procurement and the transport systems would also have significant implications for enhancing the benefits of pine needles for electricity generation. For instance, a US\$10 $\mathrm{Mg}^{-1}$ reduction in the transportation cost of pine needles would depreciate the electricity generation cost by nearly US\$ $0.008 \mathrm{~kW}^{-1}$. The average yield of $1.3 \mathrm{Mg} \mathrm{hm}^{-2} \mathrm{yr}$ is required in order for competing with coal in electricity production and the non-fuel cost. As the carbon tax levied or $\mathrm{CO}_{2}$ emission reduction applied, the electricity cost of coal was comparatively increased as to electricity generation through pine needles (Figure 4 and Figure 5). If the road transportation cost exempted, the electricity generation cost of coal would fall by $30 \%$ and would be 1.2 times less costly than that of pine needles. The location of plant also decides on the cost of electricity generation as additional road transportation cost increase the net delivery cost of coal. Hence, for grid power plants that are connected with rail road, coal would be more cost effective than pine needles, whereas for remote areas of hills, pine needles would be more promising for off-grid electricity generation. If we consider another aspect of cost analysis by involving the non-fuel cost in electricity generation cost per kWh, pine needles would not compete with 


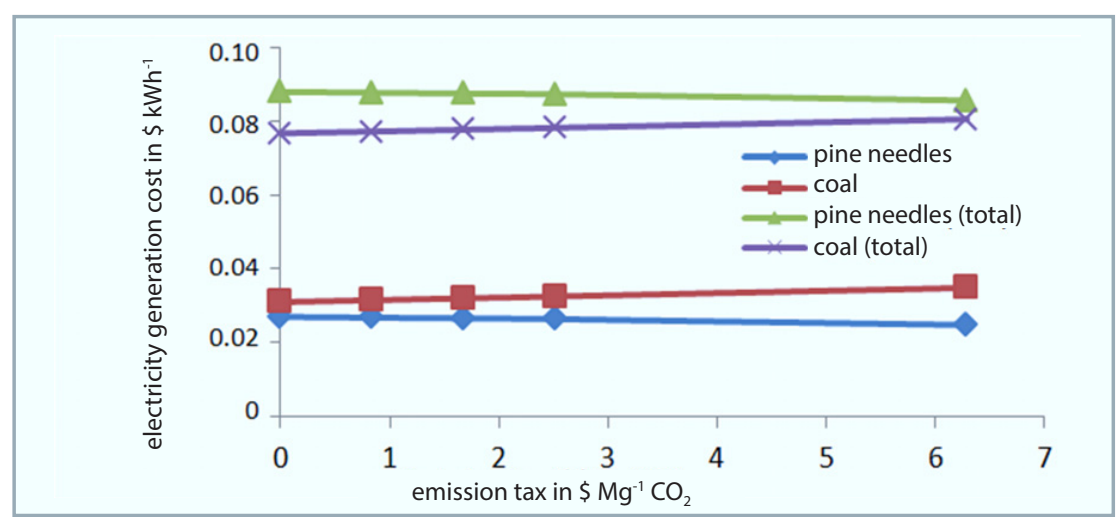

Figure 4 Electricity generation cost by fuel types at various carbon taxation Note: 'Pine needles total' and 'Coal total' represent overall costs, involving non-fuel asset in the electricity generation cost

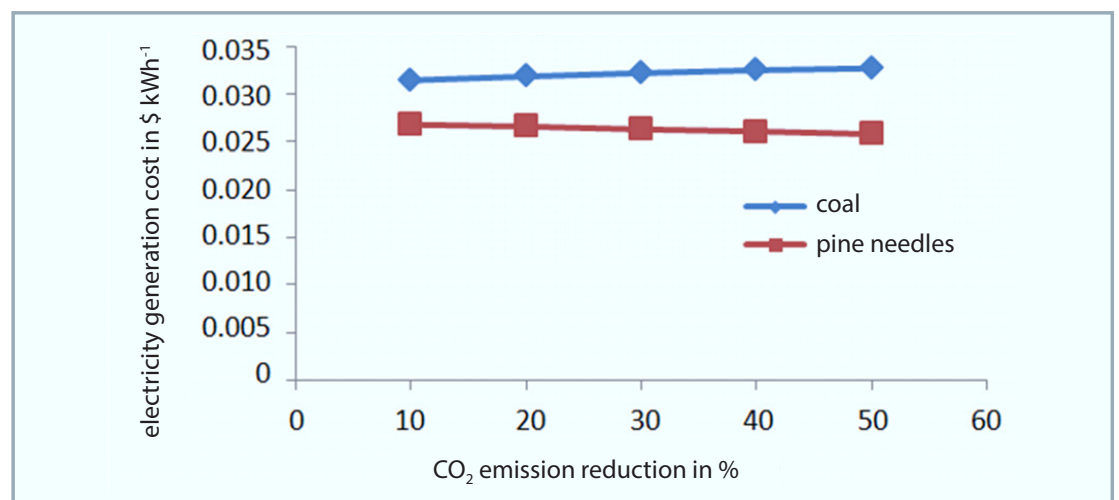

Figure 5 Electricity generation cost by fuel types under different $\mathrm{CO}_{2}$ emission reduction

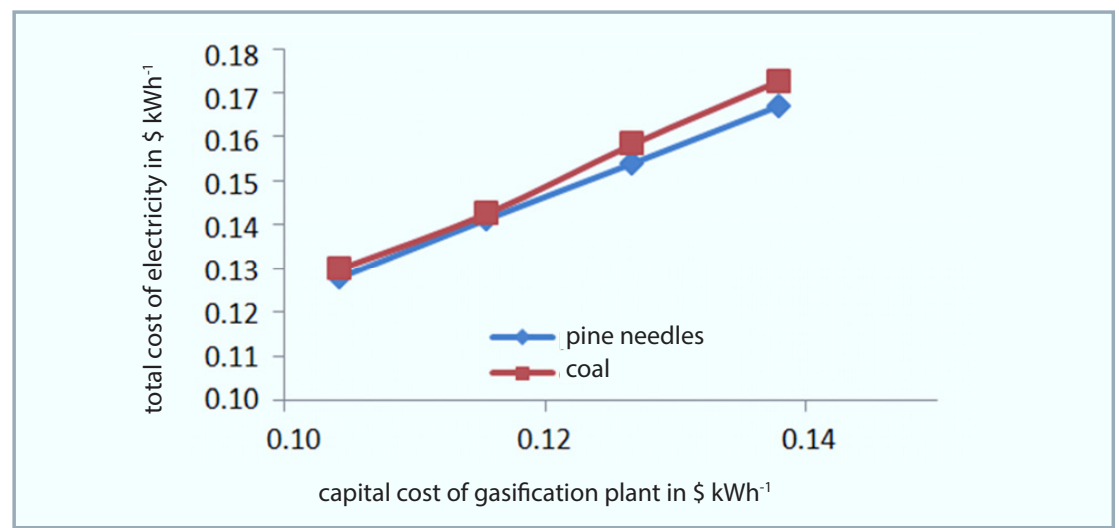

Figure 6 Total cost of electricity of fuel types under different capital cost of gasification plant (varies with lifespan of gasifier)

coal unless carbon taxation of INR 525 $\mathrm{Mg}^{-1}$ of $\mathrm{CO}_{2}$ (US\$ 8.40) or more was imposed. When pine needles yield reaches $5.05 \mathrm{Mg} \mathrm{hm}^{-2} \mathrm{yr}$, then it could compete with coal (Figure 4).

The forestry residual waste was more cost effective than coal for off-grid electricity generation, while imposing an additional road cargo cost would limit coal for grid electricity generation only. The cost of electricity generation also depends upon the capacity of gasifier. the $O \& M$ cost increases, the resulting high electricity costs and gasification efficiency would be reduced.

The forestry residual, pine needles have much better economic potential than coal for feedstock generation as well as electricity generation provided that we would have excluded non-fuel cost for the only electricity generation cost analysis. Although carbon taxation and emission reduction make pine needles more competitive than coal, yet remaining costs would be the major impediment for loose biomass energy to compete with fossil fuels. Development in bioenergy power generation technologies and improvements in the productive yield of biomass, harvesting and transportation systems are the main factors to enhance the bioenergy share in the Indian energy markets. In order to flourish a new renewable energy sector in India, power generation technologies and inclusion of more social and environmental benefits and costs in energy production consumption decision-making have to be involved for bringing the loose biomass as an alternative and cost effective energy source. Additionally, loose biomass (pine needles) also possess other environmental and social benefit such as reduction in forest fires and $\mathrm{SO}_{2}$ and $\mathrm{NO}_{x}$ emissions, rejuvenation of the country side of hill region economies, and enhancement of energy security. The social benefits regarding employment to the countryman earns INR 16000 (US\$256) per month (Uttar Pradesh Gazetteer, 1967). There is a prolific amount of forestry residue in the form of litter laid as a waste material. Using this litter for bioenergy production would benefit rural communities by creating jobs and income and diversifying the local economies. Substitutions of biomass energy for fossil fuels may also assist to reduce extra burden of oil imports and finally the nation's economic and energy vulnerability caused by heavy dependence on foreign oil. Our experimental as well as data analysis represent the regional average yield of biomass in the northern hill region of India. As a result, the competitiveness of pine needles relative to coal was reflected in power generation and feedstock production. Local, niche markets may be sufficiently different. Indeed, electricity generation powered 
by biomass alone or through co-firing biomass with coal is also competitive in some local markets or under certain circumstances (Nienow et al., 1999; Perlack et al., 1995). Moreover, various other factors affect energy prices. Energy prices do fluctuate from time to time due to economic and non-economic reasons. In fact, energy prices have hiked significantly in recent years. If this trend remains the same, the cost effectiveness of pine needles could be further improved. Hopefully, this analytical study has provided a general scenario about the competitive status of loose biomass energy in India under the consideration of carbon taxation and emission reductions. Our analysis can be expanded by adding and comparing more energy and biomass production scenarios such as co-firing, biofuel extraction through pyrolysis of loose biomass and utilization of agricultural waste. In addition, other relevant economic and technical factors such as inflation effect affect the economic evaluation for biomass production and energy conversion.

\section{Conclusion}

Increasing concern about GHGs has got our attention in biomass energy generation. Pine needles are considered to be $\mathrm{CO}_{2}$ neutral since they maintain the carbon dioxide cycle throughout their lifespan and are likely to advent as a means to offset GHG's mainly $\mathrm{CO}_{2}$ emission from the combustion of fossil fuels. This study investigates the cost competitiveness of pine needles relative to coal in feedstock production and electricity generation in the northern hill regions of India, where dearth of electricity hindered the life progress of local people. As no environmental benefits were involved in case studies of gasification plants, pine needles have no advantage over coal in electricity and feedstock production. Nevertheless, carbon taxation and emission reduction applied to coal would significantly increase its cost in India, enhancing the economic potential of pine needles in India. Regarding feedstock production costs, pine needles are far better than coal. The yield of $2.335 \mathrm{Mg} \mathrm{hm}^{-2} \mathrm{yr}$ would make pine needles competitive with coal at the carbon tax rate of about INR 325 (US\$ 5.2) per tonne of $\mathrm{CO}_{2}$. A 2.22\% increase in the yield $\left(0.736 \mathrm{Mg} \mathrm{hm}^{-2} \mathrm{yr}\right)$ of pine needles would reduce carbon taxation by about $0.47 \%$ or INR 116.56 (US\$ 1.865) per tonne of $\mathrm{CO}_{2}$. $\mathrm{A} \mathrm{CO}_{2}$ emission reduction between $40 \%$ and $50 \%$ would be required for pine needles to become as cost effective as coal. For pine needles to become competitive for the overall cost of electricity (the non-fuel and the fuel cost) generation, the carbon taxation of INR 1306.25 (US\$20.9) per tonne of $\mathrm{CO}_{2}$ or more would have to be imposed. Similarly, coal has advantages over pine needles for grid power supply under current technologies and market scenario.

\section{References}

APP. 2010. The Asia-Pacific Partnership on Clean Development and Climate. Asia-Pacific Partnership on Clean Development and Climate website. Retrieved from http:// www.asiapacificpartnership.org/ pdf/translated_versions/ Fact_Sheet_English.pdf

BRIDGEWATER, A. V 1995. The technical and economic feasibility of biomass gasification for power generation. In Fuel, vol. 74, 1995, no. 5, pp. 631-653.

BROWN, R. J. - YANUCK, R. R. 1980. Life Cycle Costing: A Practical Guide for Energy Managers. Atlanta : Fairmont Press, Inc.
CARLO, N. - HAMELINCK, C. N. - SUURS, R. A. A. - FAAIJ, A. P. C. 2005. International bioenergy transport costs and energy balance. In Biomass and Bioenergy, 2005, no. 29, pp. 114-134.

CENTRAL ELECTRICITY AUTHORITY (CEA). 2000. Performance review of thermal power stations. Retrieved from http://cea.nic.in// reports/yearly/thermal_perfm_review_rep/9900

COMMERCE CLEARING HOUSE, Inc. (CCH). 1992. U.S. Master Tax Guide. $75^{\text {th }}$ anniversary edition.

DHAUNDIYAL, A. - GUPTA, V. K. 2014. Analysis of pine needles as a substrate for gasification. In Journal of Water, Energy and Environment, 2014, no. 15, pp. 73-81.

DOGRA, S. 2010. India sets $\$ 1 / \mathrm{mt}$ clean coal tax for domestic producers/importers. Platts International Coal Report.

GRESHAM, C. A. 1982. Litterfall patterns in mature loblolly and longleaf pine stands in coastal South Carolina. In Forest Science, vol. 28, 1982, no. 2, pp. 223-231.

GUTTIKUNDA, K. - JAWAHAR, P. 2014. Atmospheric emissions and pollution from the coal-fired thermal power plants in India. In Atmospheric Environment, 2014, no. 92, pp. 449-460.

HALL, D. O. - ROSILLO-CALLE, F. - WILLIAMS, R. H. - WOODS, J. 1993. Biomass for energy: Supply prospects. In Johansson, T. B. Kelly, H. - Amulya, K. N. R. - Williams, R. H. (editors). Renewable Energy, Sources for Fuels and Electricity. Washington, D.C. : Island Press, 1993, pp. 593-653.

HORLOCK, J. H. 1995. Combined power plants - past, present and future. In Journal of Engineering for Gas Turbines and Power, vol. 117,1995 , no. 4, pp. 608-616.

ISLEGEN, Ö. - REICHELSTEIN, S. 2011. Carbon capture by fossil fuel power plants: an economic analysis. In Management Science, 2011, no. 57, pp. 21-39.

JONES, B. et al. 2008. Recent emission-reduction policy initiatives. In Chapter 4. Climate change and the global economy (Tamirisa et al.). In World Economic and Financial Surveys: World Economic Outlook: Housing and the Business Cycle. A survey by staff of the IMF. Washington, D.C., International Monetary Fund. Retrieved from http://www.imf.org/

LAWRENCE, D. M. - SLATER, A. G. 2005. A projection of severe near-surface permafrost degradation during the $21^{\text {st }}$ century. In Geophysical Research Letters, 2005, no. 32(L24401), p. 1-5.

NIENOW, S. - McNAMARA, K. - GILLESPIE, A. - PRECKEL, P. 1999. A model for the economic evaluation of plantation biomass production for co-firing with coal in electricity production. In Agricultural and Resource Economics Review, vol. 28, 1999, no. 1, pp. 106-118.

PALM, T. - QAYUM, A. 1985. Private and Public Investment Analysis. Cincinnati, South-Western Publishing Co.

PEARSON, N. O. 2010. India to raise $\$ 535$ million from carbon tax on coal. Bloomsberg Businessweek, 1 July.

PERLACK, R. - WRIGHT, L. - HUSTON, M. - SCHRAMM, W. 1995. Biomass fuel from woody crops for electricity power generation. ORNL-6871. US Department of Energy Oak Ridge National Laboratory, TN.

SENGUPTA, D. - BUREAU, ET. 2014. Coal India Limited: Coal India can expect higher realizations from e-auctions with blocks likely to be returned. Retrieved from http://articles.economictimes. indiatimes.com/

STERN, N. 2007. Stern Review on the Economics of Climate Change (pre-publication edition). Cambridge, New York, Cambridge University Press. Retrieved from http://webarchive.nationalarchives.gov.uk/

UTTARAKHAND Renewable Energy Development Agency (UREDA). 2014. Report on availability of biomass in Uttarakhand.

UTTAR PRADESH GAZETTEER - Pithoragarh District. 1967. Chapter V Industries. Retrieved from http://pithoragarh.nic.in/files/ Gazetteer/industries.pdf 